J. Amer. Soc. Hort. ScI. 120(3):491-496. 1995.

\title{
Sucrose Ester-based Coatings Formulated with Food-compatible Antioxidants in the Prevention of Superficial Scald in Stored Apples
}

\author{
A.D. Bauchot and P. John \\ Department of Agricultural Botany, Plant Science Laboratories, University of Reading, P.O. Box 221, \\ Reading, RG6 2AS, U.K. \\ Y. Soria and I. Recasens \\ Area de Post- Collita, Universitat de Lleida, Institut de Recerca I Tecnologia Agroalimentàries, Alcalde \\ Rovira Roure 117, 25006 Lérida, Spain
}

Additional index words. Malus domestics, scald index, Semperfresh, ascorbyl palmitate, n-propyl gallate, diphenylamine

\begin{abstract}
Treatments were applied in Italy, United Kingdom, and Spain to test their effectiveness in controlling superficial scald in apples (Malus domestica Borkh.) after cold storage. In Italy where mature 'Red Chief' and 'Golden Delicious' were stored at 3-4C for 4 months, scald incidence was reduced by postharvest dipping in a sucrose-ester based coating, Semperfresh, formulated with the antioxidants, ascorbyl palmitate, and n-propyl gallate. In the United Kingdom and Spain, early harvested 'Granny Smith' were stored at $0 \mathrm{C}$ for 4 and 6 months. In the United Kingdom, ascorbyl palmitate applied with Semperfresh significantly reduced scald upon withdrawal from 4 months of storage near $0 \mathrm{C}$, but not after 10 days at room temperature. Bringing the apples to ambient temperature for 20 hours 1 month into cold storage reduced scald almost as much as diphenylamine application, but the beneficial effects seen after $\mathbf{4}$ months of cold storage did not persist after 6 months of storage. In Spain, controlled atmosphere storage $\left(3 \% \mathrm{O}_{2}+3 \% \mathrm{CO}_{2}\right)$ was as effective as diphenylamine treatment, even after 6 months of storage; $\mathrm{CaCl}_{2}$ was slightly effective after 4 months of storage, but none of the coating treatments significantly reduced scald. Treatments applied after 6 weeks were ineffective.
\end{abstract}

Superficial scald is a physiological disorder appearing during long term-storage of apples and pears (Fidler et al., 1973; Meigh, 1970). When apples are removed from the cold store to room temperature, irregular brown patches appear on the skin due to the browning of hypodermal cells (Bain, 1956). The patches darken and expand during subsequent shelf life. When cold storage is extended the symptoms cart appear even before apples are removed from the cold room (Fidler et al., 1973 ; Meigh, 1970).

Diphenylamine (DPA) and 6-ethoxy-1,2,-dihydro-2,2,4trimethylquinoline (ethoxyquin) are potent inhibitors of scald development, and they have been used commercially to control scald (Smock, 1957). Consistent with their proposal that scald resulted from the oxidation of $\alpha$ - farnesene to conjugated trienes, Huelin and Coggiola (1970) demonstrated that DPA inhibited $\alpha-$ farnesene oxidation in vitro and in vivo. Consequently, they suggested that DPA and ethoxyquin act as antioxidants in controlling scald. Recently. concern over residues has led to the banning or phasing out of DPA and ethoxyquin in many countries. As possible alternative measures, controlled-atmosphere (CA) storage (Lau, 1993; Patterson and Workman, 1962) and Ca dips (Poovaiah, 1986) can be effective and have been considered. In addition, while the amine-type antioxidants appear to be the most effective anti-scald agents (Anet and Coggiola, 1974), butylated hydroxytoluene has reduced scald on 'Cortland', 'Delicious' (Gough et al., 1973) and 'Granny Smith' apples (Little et al., 1980;

Received for publication 17 Mar. 1994. Accepted for publication 22 Dec. 1994. This work was supported by the EC ECLAIR Programme (project no. AGREE 001 5), and A.D. Bauchot was supported with EC grant no. B/AGRE913016. We thank Surface Systems International for advice and materials, Godfrey Curtis for helping plan the work and for a valued collaboration, P. Domenichini (SIPCAM, Italy) for carrying out the commercial trial, and C. Moggia for statistical advice. Mention of trade name, proprietary product, or vendor does not constitute an endorsement or warranty by the authors or their institutes. The cost of publishing this paper was defrayed in part by the payment of page charges. Under postal regulations, this paper therefore must be hereby marked advertisement solely to indicate this fact.
Wills and Scott, 1977). Therefore, the use of other food-compatible antioxidants like n-propyl gallate and ascorbyl palmitate could be an alternative to DPA and warrants investigation. In addition, beneficial effects of sucrose ester-based coatings in maintaining the quality of pome fruit have been reported (Chu, 1986; Drake et al., 1983; Meheriuk and Lau, 1988; Miszczak, 1994; Smith and Stow, 1984). Thus, the aim of the present study was to examine, in relation to more conventional treatments, the effectiveness of the antioxidants ascorbyl palmitate and n-propyl gallate applied with the sucrose ester-based coating, Semperfresh, as scald inhibitors. Scald incidence is notoriously variable, depending on many interacting factors (Ingle and D' Souza, 1989); therefore, to strengthen any conclusions, the work was carried out at three sites: in Italy, United Kingdom, and Spain.

\section{Materials and Methods}

Trial in Italy. In an initial trial under commercial conditions in northern Italy, locally grown 'Red Chief' and 'Golden Delicious' apples were dipped for $30 \mathrm{sec}$ in the formulations indicated, and then stored at 3-4C and 58\%-67\% relative humidity. Three $10-$ apple replicates were used for each cultivar. Apples were transferred from store to $18-20 \mathrm{C}$ after 2 and 4 months, and the percentage of fruit affected by scald was noted after 10 days at ambient temperature.

Experiments in United Kingdom and Spain. Experiments were carried out with 'Granny Smith' apples at two sites: Reading, U. K., and Lérida, Spain. To ensure a significant incidence of scald, apples were harvested before the commercial picking date. For the United Kingdom site, they were picked on 29 Sept. 1992 in Moissac, France, transported to the Univ. of Reading, United Kingdom under commercial conditions (nonrefrigerated), and stored at $0 \pm 1 \mathrm{C}$ and $95 \%$ relative humidity under normal atmosphere on 1 Oct. In Spain, apples were picked on 13 Oct. 1992 in Lérida, Spain and stored at $0 \pm 1 \mathrm{C}$ under normal atmosphere, unless stated otherwise. 


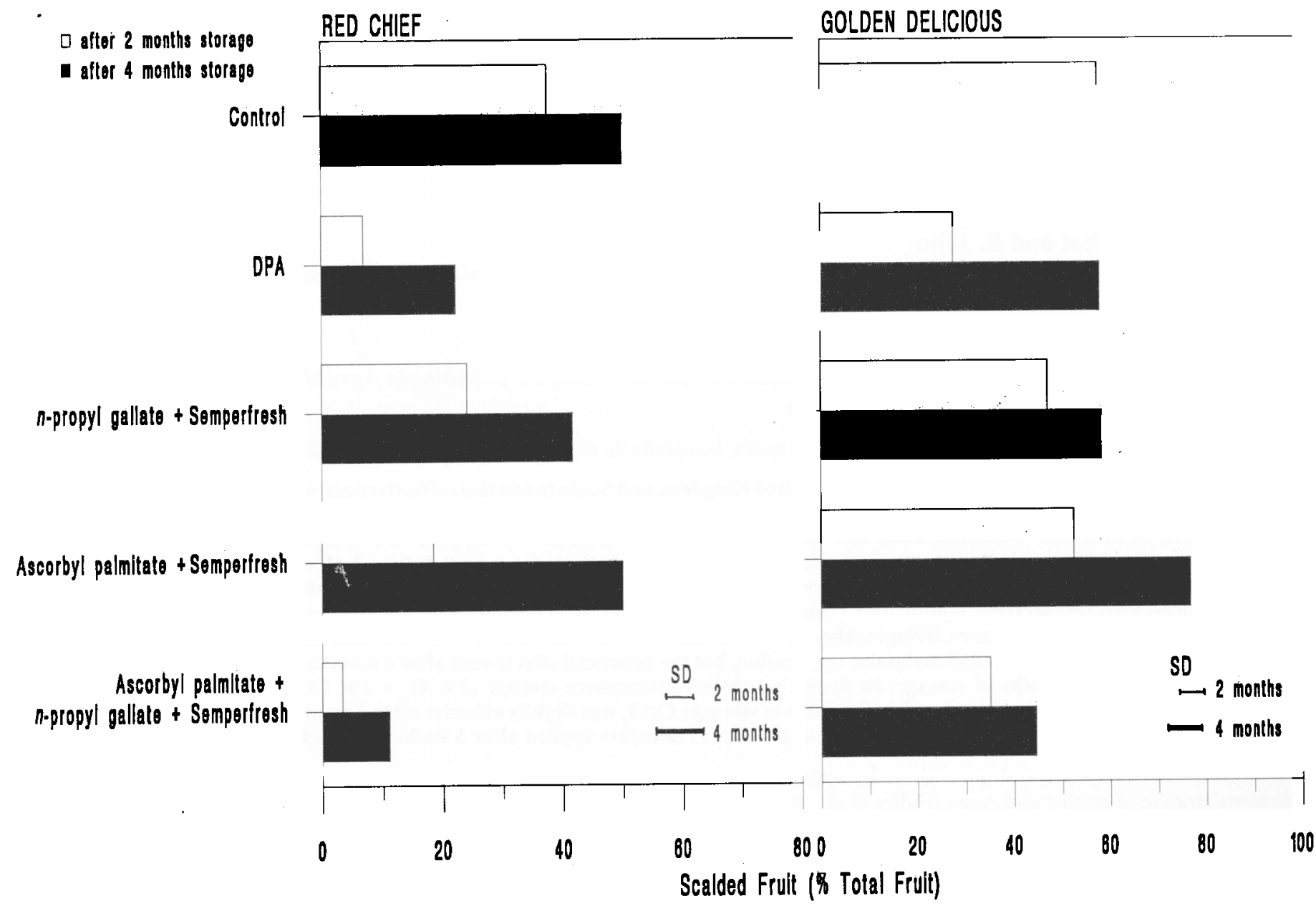

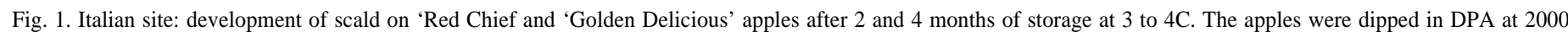

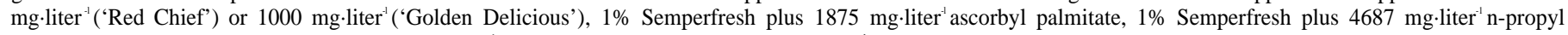
gallate, or in $1 \%$. Semperfresh plus $1875 \mathrm{mg} \cdot \operatorname{liter}^{-1}$ ascorbyl palmitate plus $1875 \mathrm{mg} \cdot l_{\text {liter }}^{-1} \mathrm{n}$-propyl gallate.

The treatments were carried out by dipping at least three replicates per treatment. Each replicate consisted of 10 apples. At both sites, apples were dipped just after harvest in DPA at 2500 $\mathrm{mg} \cdot \mathrm{liter}^{-1}$ or in Semperfresh at $1 \%(\mathrm{w} / \mathrm{v})$. Apples were also treated with $1875 \mathrm{mg} \cdot$ liter $^{-1}$ ascorbyl palmitate in 1\% Semperfresh, 4867 $\mathrm{mg} \cdot$ liter $^{-1}$ n-propyl gallate in $1 \%$ Semperfresh, or $1875 \mathrm{mg} \cdot$ liter $^{-1}$ ascorbyl palmitate and $1875 \mathrm{ppm}$ n-propyl gallate in $1 \%$ Semperfresh. These emulsions were prepared and supplied by Surface Systems International Ltd, East Challow, U.K. Additionally, in Spain, some apples were dipped at harvest in $1 \% \mathrm{CaCl}_{2}$, while others were kept in $\mathrm{CA}\left(3 \% \mathrm{O}_{2}, 3 \% \mathrm{CO}_{2}\right)$.

Four weeks into storage in the United Kingdom and 6 weeks into storage in Spain, nontreated apples were removed overnight to room temperature, then replicates were treated with $1 \%$ Semperfresh. Some replicates were kept in the same conditions without treatment as a control. The apples were allowed to dry for $4 \mathrm{~h}$ and returned to the cold room. Apples were removed from cold storage to room temperature for $\approx 20 \mathrm{~h}$.

After 4 and 6 months of storage, replicates were removed to room temperature and assessed after 1, 4, and 10 days for the incidence and severity of scald. Severity of scald was scored for each apple as none, light ( $<25 \%$ of the surface area affected), moderate (25\%-50\%), and severe $(60 \%)$ and expressed as an index according to Lurie et al. (1991) : index $=[(1 \times \%$ lightly affected fruit $)+(2 \times \%$ medium affectedfruit $)+$ $(4 \times \%$ severely affected fruit) $)] / 4$.

\section{Results}

Trial in Italy. In the trial carried out in Italy (Fig. 1), n-propyl gallate and ascorbyl palmitate applied with Semperfresh reduced the incidence of scald, their effectiveness varying with cultivar and time of storage. A more consistent scald reduction, comparable to that obtained with DPA, was obtained when a combination of $n$ propyl gallate and ascorbyl palmitate was applied with Semperfresh (Fig. 1). The results of this initial trial, together with similar results obtained elsewhere (Kallay, 1994), were sufficiently encouraging to provide the basis for the principal, more detailed investigations described below.

United Kingdom site. After 4 months of cold storage and 1 day at room temperature, the scald index of the control apples was 23 (Fig. 2), corresponding to $<10 \%$ scalded area on average. After 10 days at room temperature, the index increased to 56 , and all the apples were scalded and unmarketable. The DPA treatment reduced significantly the scald index after 10 days at room temperature to $<5$ although $17 \%$ of the apples was affected. When used alone, Semperfresh did-not reduce scald from the control values, but when an antioxidant was present with the Semperfresh, scald was less evident the first day at room temperature after removal from storage. However, the beneficial effects of n-propyl gallate either alone or in addition to ascorbyl palmitate did not last during the shelf life; after 4 and 10 days, the "scald indices increased to 


\section{Scald Index}

\section{Treatments at Harvest $\begin{array}{llllllllllll}0 & 10 & 20 & 30 & 40 & 50 & 60 & 70 & 80 & 90 & 100\end{array}$}

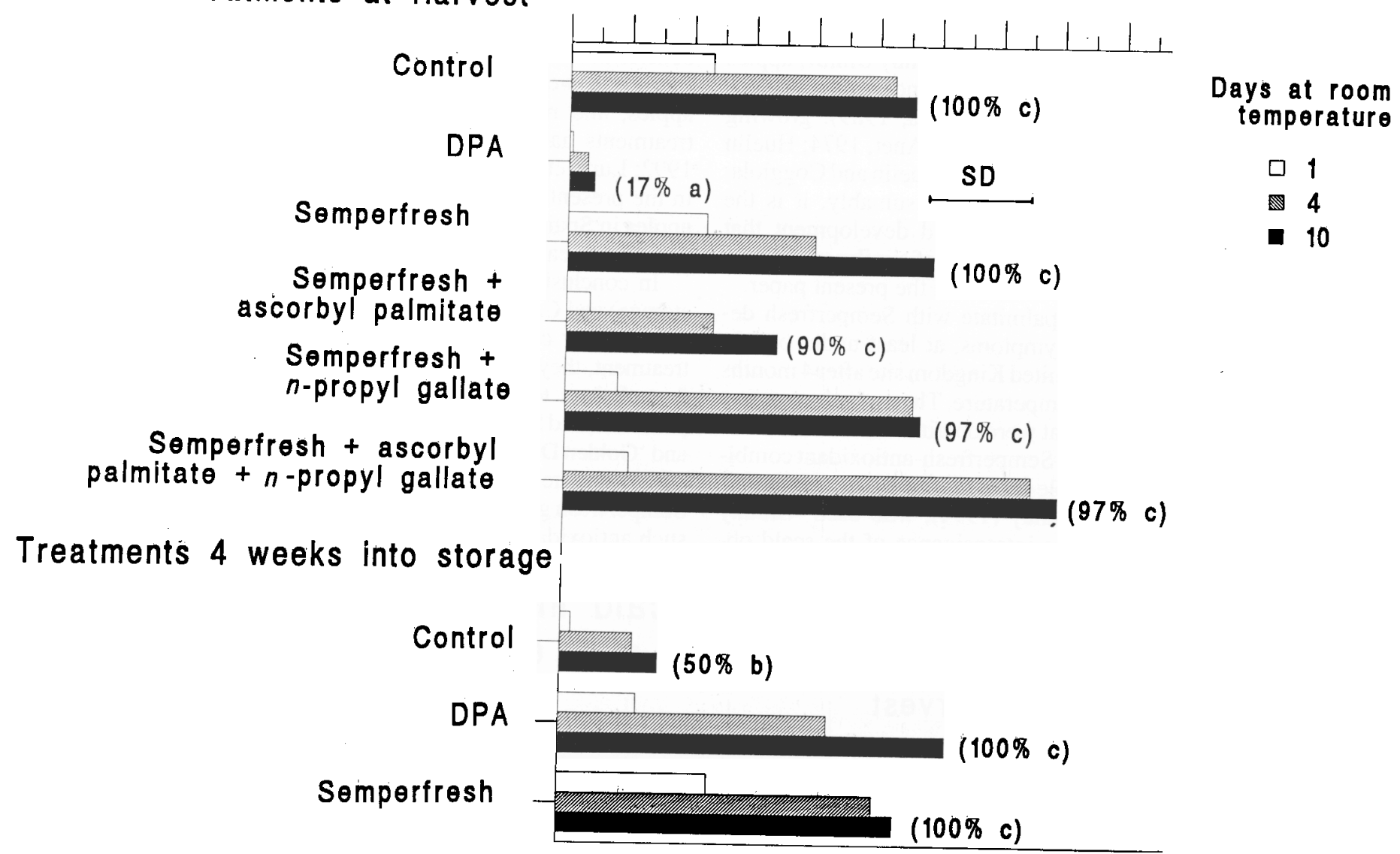

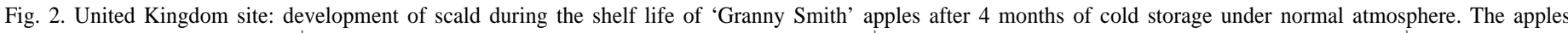
were dipped in $2500 \mathrm{mg} \cdot$ liter $^{-1} \mathrm{DPA}, 1 \%$ Semperfresh, $1 \%$ Semperfresh plus $1875 \mathrm{mg} \cdot$ liter $^{-1}$ ascorbyl palmitate, $1 \%$ Semperfresh plus $4687 \mathrm{mg} \cdot 1$ iter ${ }^{-1} \mathrm{n}$-propyl gallate, or in $1 \%$ Semperfresh plus $1875 \mathrm{mg} \cdot$ liter $^{-1}$ ascorbyl palmitate plus $1875 \mathrm{mg} \cdot$ liter $^{-1} \mathrm{n}$-propyl gallate. The treatments were carried out either immediately after harvest or 4 weeks into cold storage. Scald index $=[(1 \times \%$ lightly affected fruit $)+(2 \times \%$ medium affected fruit $)+(4 \times \%$ severely affected fruit $)] / 4$. Numbers in parentheses show the mean percentages of apples that were scalded after 10 days at room temperature. Numbers followed by the same letter are not significantly different ( LSD $_{0.05}$ ). Data transformed to arcsin $\sqrt{ } \%$ for analysis.

those of the controls. Only the application of ascorbyl palmitate combined with Semperfresh significantly reduced the scald index after 10 days at room temperature, and even then, $90 \%$ of the apples was scalded on $>10 \%$ of their surface.

Removing the apples to room temperature for $20 \mathrm{~h}$ after 4 weeks of cold storage reduced scald development to an extent similar to that observed after DPA treatment at harvest (Fig. 2). However, if at this time apples were treated with Semperfresh or DPA, the beneficial effect of the warming treatment disappeared (Fig. 2).

After 6 months of cold storage and only 1 day at room temperature, all of the control apples were scalded and had a high scald index (Fig. 3). Again, DPA treatment reduced scald development. Among all other treatments, only the combination of Semperfresh with ascorbyl palmitate gave a scald index $<45$ after 1 day at room temperature, and, after 10 days of shelf life, all treatments except DPA at harvest resulted in $100 \%$ scald (Fig. 3). Thus, some treatments other than DPA decreased the severity of scald symptoms, but none reduced the incidence of scald.

Spanish site. After 4 months of cold storage, apples treated just after harvest did not show any symptoms after 1 day at room temperature (Fig. 4). After 10 days at room temperature, all of the control apples were scalded, but with a scald index <50. DPA treatment and CA storage almost completely controlled scald, but treatment with Semperfresh alone or with added antioxidmts resulted in nearly $100 \%$ scald. After 10 days at room temperature, only $60 \%$ of the apples treated with $\mathrm{CaCl}_{2}$ was scalded, and the scald index was half that of the control. No treatment applied after 6 weeks at $0 \mathrm{C}$ reduced scald.

After 6 months of cold storage and 10 days at room temperature, all the control apples were scalded, with a scald index of 50 (Fig. $5)$. For the apples either treated with DPA or kept in CA storage, the proportion of scalded apples was lower $(50 \%$ and $70 \%$, respectively), and the scald indices were $<20$ (Fig. 5). None of the other treatments significantly reduced scald.

\section{Discussion}

As with many cultivars, 'Granny Smith' apples are more sensitive to superfluid scald when harvested early (Anet, 1972; Huelin and Coggiola, 1968; Lurie et al., 1991). The present results are consistent with these findings: in the United Kingdom and Spain, after 4 months of cold storage and 10 days at room temperature, $100 \%$ of the control apples developed scald, many with severe symptoms. DPA treatment at harvest reduced but did not prevent scald on these fruit and was less effective after 6 than after 4 months. CA treatment (applied only in Spain) gave remark- 
ably good control of scald after 4 months and slightly less control than DPA after 6 months.

Other edible coatings, comparable to Semperfresh, have reduced superficial scald significantly on 'd'Anjou' pears (Meheriuk and Lau, 1988), while Kerbel et al. (1989) noted an enhancement of scald development on early harvested 'Granny Smith' apples treated with Semperfresh. Many factors influence scald development on 'Granny Smith' (Ingle and D'Souza, 1989): growing conditions (Bramlage et al., 1993); maturity (Anet, 1974; Huelin and Coggiola, 1968) and storage conditions (Huelin and Coggiola, 1970; Little et al., 1985; Meigh, 1970). Presumably, it is the interaction between these factors and scald development that accounts for the differences in effectiveness of similar treatments applied in the United Kingdom and Spain in the present paper.

The application of ascorbyl palmitate with Semperfresh delayed the appearance of scald symptoms, at least under certain conditions: most notably at the United Kingdom site after 4 months cold storage and 1 day at room temperature. These results contrast with the more positive effects that were obtained in the trial at the Italian site described here, where Semperfresh-antioxidant combinations were applied to other apple cultivars harvested at commercial dates, and the results of Kallay (1994), who used 'Granny Smith'. We attribute the relative intransigence of the scald ob- served here with 'Granny Smith' apples to the early, precommercial harvest date.

In the United Kingdom, warming the apples after 4 weeks of cold storage gave a control of scald closest to that obtained with a postharvest DPA treatment. Previously, Smith (1959) reported the beneficial effects of a 5-day warming period occurring between the fourth and twentieth week of cold storage of 'Bramley's Seedling' apples, and reductions of scald damage with prestorage heat treatments have been described many times (Klein and Lurie, 1992; Lurie et al., 1991; Porritt and Lidster, 1978). Nevertheless, in the present work, warming the apples was ineffective for the apples in Spain. Again, this underlines the variability in response to similar treatments for apples of different origins.

In conclusion, warming the apples (by withdrawal from cold storage) and CA storage were effective with 'Granny Smith' under some of our conditions, but, as commercial alternatives to DPA treatment, they are unlikely to be cost-effective. Among the novel formulations tested, a combination of n-propyl gallate, ascorbyl pahnitate, and Semperfresh was the most effective with 'Red Chief, and 'Golden Delicious' apples, harvested at commercial date. With early harvested 'Granny Smith', ascorbyl palmitate applied with Semperfresh gave a limited scald control. Further development of such antioxidant-coating formulations appears to be justified.

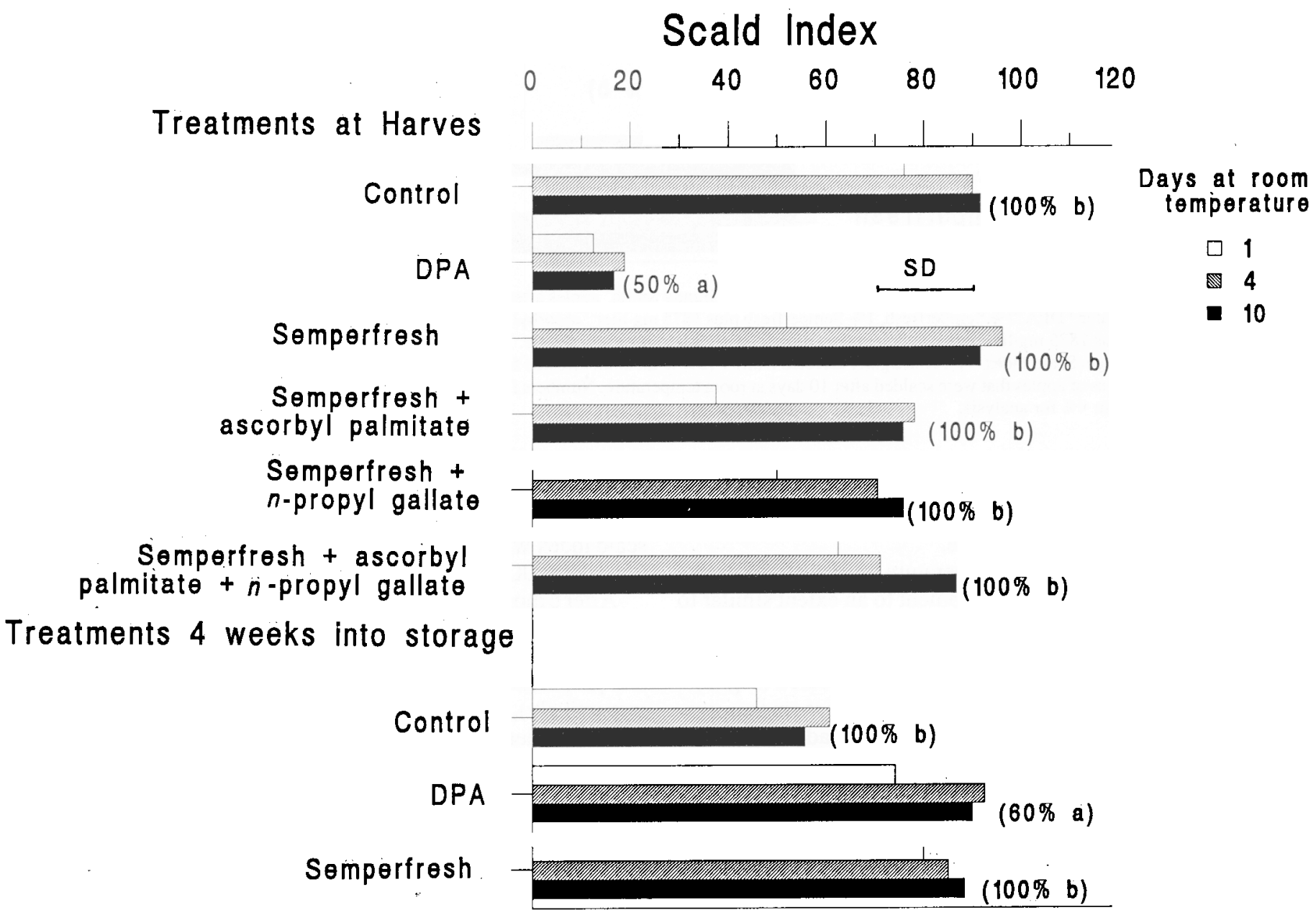

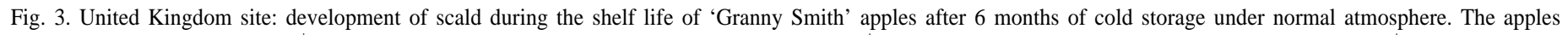

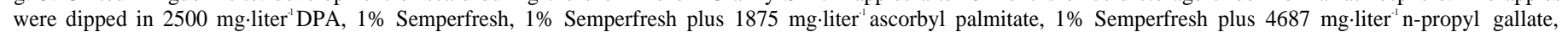

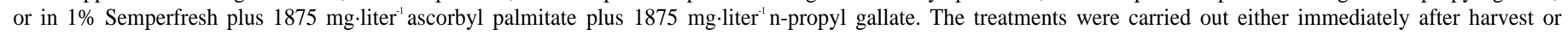

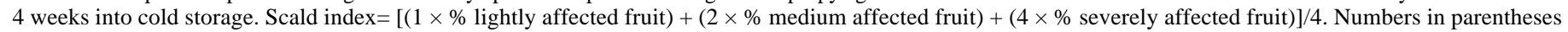

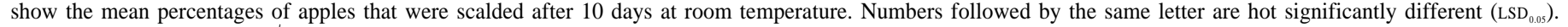
Data transformed to arcsin $\sqrt{ } \%$ for analysis. 


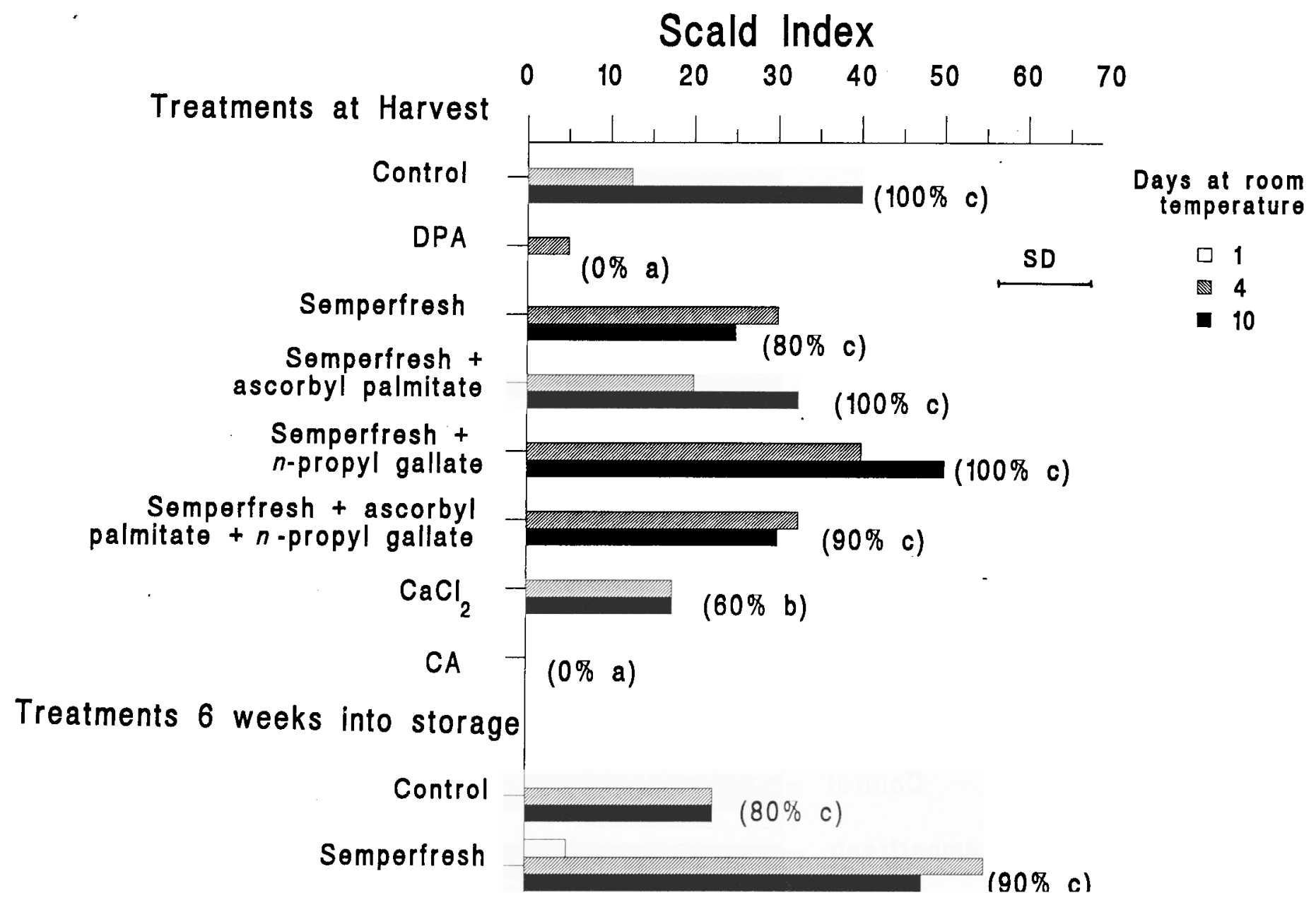

Fig. 4. Spanish site: development of scald during the shelf-life of 'Granny Smith' apples after 4 months of cold storage. The apples were dipped in $2500 \mathrm{mg} \cdot$ liter ${ }^{-1} \mathrm{DPA}$, 1\% Semperfresh, 1\% Semperfresh plus 1875 ascorbyl palmitate, $1 \%$ Semperfresh plus $4687 \mathrm{mg}$-liter n-propyl gallate, $1 \%$ Semperfresh plus $1875 \mathrm{mg}$-liter ascorbyl palmitate plus $1875 \mathrm{mg} \cdot \mathrm{liter}^{-1} \mathrm{n}$-propyl gallate, or in $1 \% \mathrm{CaCl}_{2}$. The treatments were carried out immediately after harvest or 6 weeks into storage. A further set of otherwise untreated apples was stored immediately after havest in controlled atmosphere (CA) conditions. Scald index $=[(1 \times \%$ lightly affected fruit $)+$ $(2 \times \%$ medium affected fruit) $+(4 \mathbf{x} \%$ severely affected fruit) $) / 4$. Numbers in parentheses show the mean percentages of apples that were scalded after 10 days at room temperature. Numbers followed by the same letter are not significantly different $\left(\mathrm{LSD}_{005}\right)$.

\section{Literature Cited}

Anet, E.F.L.J. 1972. Superficial scald, a functional disorder of stored apples. IX. Effect of maturity and ventilation. J. Sci. Food Agri. 23:763769.

Anet, E.F.L.J. 1974. Superficial scald, a functional disorder of stored apples. XI. Apple antioxidants. J. Sci. Food Agr. 25:299-304.

Anet, E. F.L.J. and I.L. Coggiola. 1974. Superficial scald, a functional disorder of stored apples. X. Control of $\alpha$ - farnesene autoxidation. J. Sci. Food Agr. 23:763-769.

Bain, J.M. 1956. A histological study of the development of superficial scald in 'Granny Smith' apples. J. Hort. Sci. 31:234-238.

Bramlage, W.J., C.L. Barden, and C.B. Watkins. 1993. Comparing potential predictors of scald susceptibility of apples (Malus domestica Borkh.). Acta Hort. 326:237-244.

Chu, C.L. 1986. Poststorage application of TAL Pro-long on apples from controlled atmosphere storage. HortScience 21:267-268.

Drake, S. R., J.K. Fellman, and J.W. Nelson. 1983. Postharvest use of sucrose polyesters for extending the shelf-life of stored 'Golden Delicious' apples. J. Food Sci. 52: 1283-1285.

Fidler, J. C., B.G. Wilkinson, K.L. Edney, and R.O. Sharples. 1973. Injuries to the skin of the fruit, p. 67-75. In: J.C. Fidler (ed.). The biology of apple and pear storage, part 2. Commonwealth Agr. Bur., East Mailing, England.

Gough, R.E., V.G. Shutak, C.E. Olney, and H. Day. 1973. Effect of butylatedhydroxytoluene (BHT) on apple scald. J. Amer. Soc. Hort. Sci. 98:14-15.

Huelin, F.E. and I.M. Coggiola. 1968. Superficial scald, a functional disorder of stored apples. IV. Effect of variety, maturity, oiled wraps and diphenylarnine on the concentration of $\alpha$-famesene in the fruit. J. Sci. Food Agric. 19:297-301.

Huelin, F.E. and I.M. Coggiola. 1970. Superficial scald, a functional disorder of stored apples. V. Oxidation of $\alpha$ - farnesene and its inhibition by diphenylamine. J. Sci. Food Agr. 21:44-48.

Ingle, M. and M.C. D'Souza. 1989. Physiology and control of supeficial scald of apples: A review. HortScience 24:28-31.

Kallay, T. 1994. New measures against superficial scald of apples. Acts Hort. 368:220-224.

Kerbel, E., F.G. Mitchell, A.A. Kader, and G. Meyer. 1989. Effect of "Semperfresh" coating on postharvest life, internal atmosphere modification and quality maintenance of 'Granny Smith' apples. Proc. 5th Intl. Cont. Atm. Res. Conf., Wenatchee, Wash., 14-16 June 1989, vol. 1.

Klein, J.D. and S. Lurie. 1992. Prestorage heating of apple fruit for enhanced postharvest quality: Interaction of time and temperature. HortScience 27:326-328.

Lau, O.L. 1993. Scald and its control: The North-American situation. Acts Hort. 326:225-230.

Little, C. R., H.J. Taylor, and F. McFarlane. 1985; Postharvest and storage factors affecting superficial scald and core flush of 'Granny Smith' apples. HortScience 20:1080-1082. 


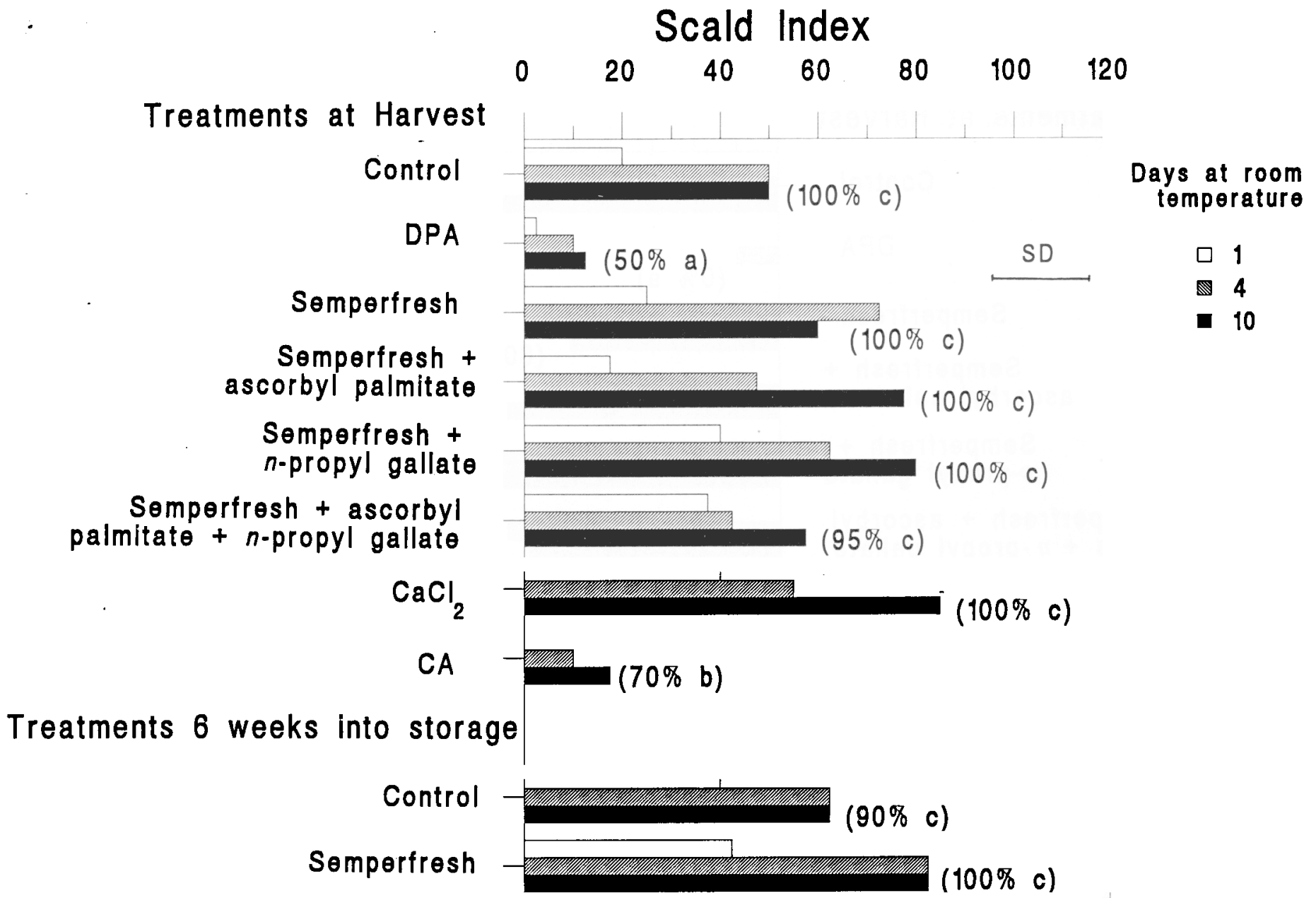

Fig. 5. Spanish site development of scald during the shelf-life of 'Granny Smith' apples after 6 months of cold storage. The apples were dipped in $2500 \mathrm{mg}$-liter ${ }^{-1} \mathrm{DPA}$, $1 \%$ Semperfresh, $1 \%$ Semperfresh plus $1875 \mathrm{mg} \cdot \cdot_{\text {liter }}{ }^{-1}$ ascorbyl palmitate, $1 \%$ Semperfresh plus $4687 \mathrm{mg} \cdot \mathrm{liter}^{-1} \mathrm{n}$-propyl gallate, $1 \%$ Semperfresh plus $1875 \mathrm{ppm}$ ascorbyl palmitate plus $1875 \mathrm{mg} \cdot$ liter ${ }^{-1} \mathrm{n}$-propyl gallate, or in $1 \% \mathrm{CaCl}_{2}$. The treatments were carried out immediately after harvest or 6 weeks into storage. A further set of otherwise untreated apples was stored immediately after harvest in controlled atmosphere $(\mathrm{CA})$ conditions. Scald index $=[(1 \times \%$ lightly affected fruit $)+$ $(2 \times \%$ medium affected fruit $)+(4 \times \%$ severely affected fruit $)] / 4$. Numbers in parentheses show the mean percentages of apples that were scalded after 10 days at room temperature. Numbers followed by the same letter are not significantly different $\left(\operatorname{LSD}_{0.05}\right)$.

Little, C. R., H.J. Taylor, and I.D. Peggie. 1980. Multiformulation dips for controlling storage disorders of apples and pears. II. Assessing scald inhibitors. Scientia Hort. 13:315-321.

Lune, S., J.D. Klein, and R. Ben-Arie. 1991. Prestorage heat treatment delays development of superficial scald on 'Granny Smith' apples. HortScience 26:166-167.

Meigh, D.F. 1970. Apple scald, p. 555-569. In: A.C. Hulme (ed.). The biochemistry of fruits and their products. vol 1. Academic Press, London.

Meheriuk, M. and O.L. Lau. 1988. Effect of two polymeric coatings on fruit quality of 'Bartlett' and 'd'Anjou' Pears. J. Amer. Soc. Hort. Sci. 113:222-226.

Miszczak, A. 1994. Effect of Pro-long treatment on quality of stored apples. Acta Hort. 368:552-557.

Patterson, M.E. and M. Workman. 1962. The influence of oxygen and carbon dioxide on the development of apple scald. Proc. Amer. Soc.
Hort. Sci. 80:130-136.

Poovaiah, B. W. 1986. Role of calcium in prolonging storage life of fruits and vegetables. Food Technol. 58:86-89.

Porritt, S.W. and P.D. Lidster. 1978. The effect of pre-storage heating on ripening and senescence of apples during cold storage. J. Amer. Sot. Hort. Sci. 103:584-587.

Smith, W.H. 1959. Control of superficial scald in stored apples. Nature 183:760.

Smith, S.M. and J.R. Stow. 1984. The potential of a sucrose ester coating for improving the storage and shelf-life qualities of Cox's Orange Pippin apples. Ann. Applied Biol. 104:383-391.

Smock, R.M. 1957. A comparison of treatments for the control of apple scald disease. Proc. Amer. Soc. Hort. Sci. 69:91-100.

Wills, R.B.H. and K.J. Scott. 1977. Evaluation of the use of butylated hydroxytoluene to reduce superficial scald of apples. Scientia Hort. 6:125-127. 